\title{
Kırım Savaşı (1853-56) Döneminde Propaganda: Rus Popüler Kültüründe Savaş ve Düşman İmgesi ${ }^{*}$
}

\author{
Kezban Acar ${ }^{* *}$
}

Öz

1853-1856 yılları arasında Rusya ile Osmanlı Devleti, İngiltere ve Fransa arasında yaşanan Kırım Savaşı, Rusyảnın mağlubiyetiyle sonuçlanmıştır. Esasen Osmanlı Devleti’ne karşı özelikle doğu cephesinde başarılı olan Rusya, Kırım'da Fransızlar karşısında tutunamamış; İngilizlerin deniz gücü karşısında da mağlup olmuştur. Ancak o dönemde propaganda amacıyla sıradan insanlar için üretilen lubki resimlerinde, kitaplarında ve şiirlerinde Rusya savaşın kesin kazananıdır. Bu makale, popüler resim ve edebiyattan bazı örnekleri analiz ederek, savaş dönemi Rus propagandasını değerlendirmeyi amaçlamaktadır.

\section{Anahtar kelimeler}

Kırım Savaşı, lubki, Rusya, Osmanlı Devleti, İngiltere, Fransa.

Geliş Tarihi: 10 Kasım 2016 - Kabul Tarihi: 03 Ocak 2017 Bu makaleyi şu şekilde kaynak gösterebilirsiniz: Acar, Kezban (2019). "Kırım Savaşı (1853-56) Döneminde Propoganda: Rus Popüler Kültüründe Savaş ve Düşman İmgesi”. bilig - Türk Dünyası Sosyal Bilimler Dergisi 88: 113-136.

** Prof. Dr., Celal Bayar Üniversitesi, Fen-Edebiyat Fakültesi, Tarih Bölümü - Manisa/Türkiye ORCID ID: https://orcid.org/0000-0003-4702-9778

kacar45@yahoo.com 


\section{Giriş}

Türkiye'de Kırım Savaşı ile ilgili birçok çalışma bulunmaktadır. Bunların önemli bir kısmı, Kırım Savaşı'nın, Osmanlı Devleti ile Avrupa ülkeleri arasındaki diplomatik ilişkiler açısından veya sosyo-ekonomik açıdan etkilerini inceleyen çalışmalardır (Aysal 2013, Şimşek 2013, Badem 2010, Özcan 2010, Keleş 2010, Çakır 2009, Keleş 2008, Badem 2007, Taşkın 2007, Sarınay 2006, Eldem 2006, Başbakanlık Devlet Arşivleri Genel Müdürlüğü 2006, Savaştan Barışa 150. Yıldönümünde Kırım Savaşı 2006, Dağlar 2004, Andıç, Fuat ve Süphan Andıç 2002, Şahin 1999, Özcan 1998, Karasu 1998, Şahin 1998, Terzioğlu 1991, Şimşir 1985, Yıldız 1984). Ayrıca savaşın askerî yönünü ele alan bazı spesifik çalışmalar bulunmaktadır (Ünalp 2013, Budak 1993, Besbelli 1977, Süer 1976, Sirer 1965, Gürel 1935, Kurtoğlu 1927).

Ancak görülen o ki Türkiye’de Kırım Savaşı bağlamında en çok ilgi çeken ve çalışılan konu, savaş sonrası veya sırasında Osmanlı Devleti'ne yapılan göçlerdir (Yüksel ve Karademir 2012, Demirtaş 2011, Başer 2010, Demirtaş 2009, Bayraktar 2008, Bayraktar 2007, Serbestoğlu 2006, Demirel 2005, Kazas 1994, Pinson 1993, Pinson 1972).

Önemli bir kısmında Osmanlıca kaynakların kullanıldığı bütün bu çalışmalar, genel olarak Kırım Savaşı'nı spesifik olarak da onun Osmanlı Devleti'ne etkilerini anlamak açısından son derece mühimdir. Bununla birlikte, Kırım Savaşı'nın Rusya'daki yansımalarını inceleyen tek bir çalışma bulunmaktadır. Bu da Candan Badem'in savaşın Rus ve Sovyet tarihçiliğinde ele alınış biçimi inceleyen bir makalesidir (Badem 2006: 16-23). Çalışma, Ruslardaki Kırım Savaşı algısı açısından çok önemli bir çalışma olmakla birlikte, savaşın popüler edebiyattaki veya sanattaki yansımalarına hiç değinmez. Rus popüler edebiyatı ve sanatından orijinal kaynakların incelendiği ve değerlendirildiği bu makale ise Rusyảnın savaşa bakışını farklı bir açıdan analiz etmeyi amaçlamaktadır.

\section{Savaşın Nedenleri ve Ortaya Çıkışı}

Fransa’nın Osmanlı Devleti'ndeki Katoliklerin, Rusya’nın ise Ortodoksların haklarının yeniden teyit edilmesi ile ilgili talepleri ile ortaya çıkan ve aslında Osmanlı Devleti üzerinde ve genel olarak da doğuda kimin daha etkili olacağının mücadelesi olan "Kutsal Yerler Meselesi" nin sonucunda galip çıkan Fransa oldu. Osmanlı Devleti, 1852'de başlayan görüşmeler sonucunda, Fransa’nın 1740 kapitülasyonları ile elde ettiği "Katolikleri koruma hakkını" yenilerken, 
aynı şeyi Rusya ve Ortodokslar için yapmayı reddetti. Bu karar üzerine, Osmanlı Devleti' ne gözdağı vermek isteyen Rusya, 1853 yazında, halkının çoğu Ortodokslardan oluşan iki Osmanlı eyaletini, Eflâk ve Boğdan'ı işgal etti. Osmanlı Devleti, Rusya’ya birliklerini geri çekmesi içim kesin uyarı verdi; bunun reddedilmesi üzerine Ekim 1853'te Rusyàya savaş ilan etti.

\section{Savaşın Nedenleri}

Dönemin Çarı I. Nikolay (1825-55), Rus halkına ve Rusya’nın işgal ettiği Eflâk ve Boğdan halklarına hitap eden manifestosunda, işgal nedenini Ortodoksların haklarını korumak olarak açıkladı. "Osmanlı Devleti 1774 Küçük Kaynarca Antlaşması ile vaat edilen Ortodoks haklarını geçersiz kıldığından Rusya Bab-1 Âli’ye gözdağı vermek için adı geçen Tuna vilâyetlerini işgal etti. Eğer Osmanlı Devleti inatçılığını ve körlügünü devam ettirirse, Tanrı'nın yardımına sığınan Rusya, Ortodoks inançları ve hakları için savaşacaktır" dedi (Jelavich 1974: 95). Osmanlı Devleti' ni geçmişteki antlaşmaları ihlâl etmekle suçlarken, Rusya'yı Ortodoksların geleneksel hamisi olarak tanımladı.

Modern araştırmacılara göre ise Rusyả nın Kutsal Yerler Meselesindeki tavrının ve ardından gelen savaş kararının en önemli sebebi, 1833 Hünkâr İskelesi Antlaşması ile Boğazlar konusunda kazandığı avantajları, 1841'de Londra Boğazlar Sözleşmesi ile kaybetmesiydi. Osmanlı Devleti, 1833 Hünkâr İskelesi Antlaşması ile Rusya'nın herhangi bir Avrupa devleti ile savaşa girmesi durumunda, Boğazları o devletin savaş gemilerine kapatmayı, Rus gemilerine ise açmayı taahhüt etmişti. Boğazların yönetimini uluslararası bir komisyonun idaresine veren 1841'deki Londra Boğazlar Sözleşmesi ise, Rusya ile Osmanlı Devleti arasındaki Boğazlarla ilgili antlaşmaları geçersiz kılmıştı. Bu tarihten itibaren Rusya Osmanlı Devleti üzerindeki nüfuzunu tekrar kurmak için farklı yollar aramaya başladı. Rusya için 1852'de Fransa ile arasında çıkan "Kutsal Yerler Meselesi" bu anlamda bir firsattı; ama Osmanlı Devleti bu mesele konusunda Fransa lehine bir karar verince, hayal kırıklığına uğradı. Bundan sonra ise amaçlarına Osmanlı Devleti'nde yaşayan Ortodoksları koruma iddiasıyla ulaşmaya çalıştı. Hatta bu bizzat çar Nikolay'ın Boğdanoviç'e verdiği talimatın bir parçasıydı (Boğdanoviç 1876-77: 1/92)

John Puryear gibi tarihçilere göre ise, Nikolay'ın savaşa sebebiyet veren Tuna vilâyetlerini işgal kararının nedeni, Rusyảnın bu bölgedeki ekonomik çıkarlarıydı. Puryear bu bağlamda özellikle Tuna Nehri aracıllğıyla Eflak ve Boğdan 
bölgesinden yapılan buğday ticaretine ve bu ticaretin Rus ekonomisi için giderek artan önemine dikkat çeker (Puryear 1965: 83-89). Rusya'nın bu bölgeye yönelik politikalarının başlangıcı 1829 Edirne Antlaşması’na dayanır. 1821 'de başlayan Mora isyanına son veren ve Yunanistan'ın bağımsızlığını ilan eden 1829 tarihli Edirne Antlaşması'nın ikinci maddesine göre, Rusya, Eflak ve Boğdan'ı Osmanlı Devleti'ne iade edecekti. Ancak beşinci maddeye göre Osmanlı Devleti, Eflâk ve Boğdan'ın Rusya’nın koruması altında olacağını kabul etmekte ve Rus vatandaşlarına diğer Avrupa ülkeleri vatandaşlarına tanıdığı imtiyazları vermekteydi (Sertoğlu 2011: V/2913, Muâhedât Mecmûası 2008: IV/71-73). Rusya’nın Tuna vilâyetleri ile ilgili hakları, yedi yıl için seçilen valilere onay verme veya vermemeyi kapsıyordu. Ayrıca, bu antlaşmayla Osmanlı hükümeti, Eflâk ve Boğdan hükümetlerinin Rusyảnın isteklerini dikkate almasını ve Rusya'nın Osmanlı tarafından savaş tazminatı ödeninceye kadar birliklerini bu vilâyetlerde bırakmasını kabul etmekteydi (Jelavich 1974: 80).

1829 Antlaşması ile Eflâk ve Boğdan'ın özerkliğini sağlayan Rusya, aynı antlaşmanın üçüncü maddesine göre Tuna eyaletleri ile denizden ve karadan ticaret yapma hakkını elde etti (Sertoğlu 2011: V/2913, Muâhedât Mecmûas1 2008: IV/71-72). Bundan yararlanan Rusya, kısa bir sürede Tuna deltas1 ticaretini kontrol etmeye başladı ve bu avantajını, Tuna deltasından Avrupa pazarlarına buğday ihracatını engellemek ve bunun yerine Odesa ve Taganrog gibi Karadeniz’e kıyısı olan limanlardaki ticareti geliştirmek için kullandı. Ama bu Tuna vilâyetlerinin buğday ihracatındaki rolünü azaltmadı. Edirne Antlaşması'na göre hem Eflâk hem de Boğdan buğdaylarını istedikleri ülkelere, istedikleri fiyata satma hakkı elde etmişlerdi. Bununla birlikte, Rusya hâlâ buğday satışında Tuna vilayetleri ile başa baş gidiyordu. 1832-40 yılları arasında, Rusya’nın buğday ihracatı \%56 artmıştı ve alıcılarının başında da İngiltere gelmekteydi. Rusya için son derece olumlu olan bu tablo, İngiltere ile Osmanlı Devleti arasında imzalanan ve İngiliz mallarına uygulanan gümrük vergilerini yüzde üçe düşüren 1838 Baltalimanı Antlaşması ile değişmeye başladı (Puryear 1965: 83-89). Bu antlaşmadan sonra, İngiltere buğday ihtiyacını, yüksek vergili Rusya yerine, düşük vergilerin uygulandığı Osmanlı Devleti’nden veya onun Balkan eyaletlerinden sağlamaya başladı. İşte bu noktada Eflâk ve Boğdan, Rusya için çok daha önemli bir hale geldi. 
Çarın Osmanlı Devleti'ne savaş açmasında, kendi ordusuna ve ülkesine duyduğu asılsız güvenin de önemli bir payı olduğu söylenebilir. Savaş patlak verdiği zaman Rus ordusunun başkomutanı olan, Rusyảnın eski Osmanlı elçisi Prens Menşikov’a yazdığı 9/21 Ekim 1853 tarihli mektupta, çar bu güvenini şöyle ifade etmiştir: "İngiliz ve Fransız donanmalarının hâlâ Boğaz'a girip girmediğini bilmiyoruz, ama öyle bile olsa, onlardan kim korkar ki? Yarın Fransızlara ve İngilizlere, eğer gemileri Karadeniżde görülürse, bunu bize karşı bir hareket olarak kabul edeceğimi ve Osmanlı Devleti'ne karşı olduğu gibi, onlara karşı da harekete geçeceğimizi bildireceğim” (Reskripty I Piśma Imperatora Nikolaya 1908). Rusyảnın gücünden son derece emin olan Çar, Fransa ve İngiltere tarafindan desteklenen Osmanlı İmparatorluğu’na savaş açtı.

Kırım Savaşı sırasında Rusya’nın Tuna Ordusu Komutanlığı'na getirilecek General İvan Fyodoroviç Paskeviç’in mektuplarında da aynı kendine güveni görmek mümkündür. Ancak Paskeviç’in güveni daha çok Avrupa devletlerinin tarafsızlığına olan inancından kaynaklanıyordu. Savaşı önlemek isteyen Avrupa devletleri, Osmanlı Devleti'ni, Rusya’nın isteklerini kabul etmeye ikna etmeye çalışırken, Paskeviç, Dışişleri Bakanı Gorçakov’a yazdığı 29 Haziran 1853 tarihli bir mektupta bu güveni şu sözlerle dile getirmiştir: "Rusyảnın Tuna eyaletlerini işgalinden dolayı, Türklerin ulusal gururunda ve dini duygularındaki yükselişe rağmen, Avrupa devletlerinin Rusya ile Osmanlı Devleti arasında herhangi bir savaşa izin verecekleri çok da muhtemel değildir" (Russkaya Starina 1876/15: 1, 174). Avrupa devletlerinin uzlaştırma çabalarından cesaret alan Paskeviç̧in bu güvenle daha da ileri giderek, bazı takviyelerle Rusyànın iki-üç hafta içerisinde, Osmanlı Devleti'nin Balkanlarda işini bitirebileceğini belirttiği görülür (Russkaya Starina 1876/15: 1).

Çar, bakanları ve elçileri arasındaki yazışmalar incelendiğinde görülür ki ne çar ne bakanlar ne de elçiler, Ortodoks halklarının korunmasını, işgallerin ve savaşın bir nedeni olarak açıklamıştır. Aksine, onlara göre Rusyảnın Osmanlı Devleti ile savaşmasının nedeni Rusya’nın doğudaki nüfuzunu artırması gereğidir. Onlara göre, Balkanlardaki Ortodokslar hakları korunması gereken mazlum halklar değil, sadece muhtemel müttefiklerdir: Çar’a yazdığı bir mektupta, Paskeviç, Rusyànın Doğu Bulgaristan'ı işgal etmesini ve İstanbul'a doğru ilerlemek için Türk katliamlarından dolayı Rus birliklerini desteklemesi muhtemel Balkan Hıristiyanlarını kullanmasını tavsiye etti. 
Benzer bir şekilde, Gorçakav’a yazdığı mektupta Paskeviç, aynı önerisini biraz daha ayrıntılı bir şekilde tekrarladı: "Osmanlı İmparatorluğu’ndaki Hıristiyanların silahlandırılmasını, her zaman Rusya için son derece önemli, Türkler için ise son derece tehlikeli buldum. Hıristiyanların silahlandırılması, birliklerimizin Balkanlarda kaldıkları süre boyunca korunmasında ve onlara yiyecek malzemesinin sağlanmasında yardımcı olabilir; hatta Rus ordusunun işgallerinin veya belki de Osmanlı İmparatorluğu'nun düşüşünün bir aracı olarak hizmet edebilirler" (Russkaya Starina 1876/15: 1). Paskeviç benzer görüşlerini savaş ilân edildikten sonra da yineledi ve Gorçakov’a şunları yazdı: "Eğer Ruslar, savaşı paganlara karşı açılmış bir savaş olarak gösterirse, Hersekliler ve diğer Hıristiyanlar da onlara katılacaktır” (Russkaya Starina 1876/15: 1). Bu ifadeler, Rus diplomatlarının Ortodoksları korumak politikasını, Rusya'nın Balkanlarda Osmanlı Devleti aleyhine genişlemesinin bir aracı olarak gördüklerine işaret eder.

Resmî ideolojiye ve Rusyả nın çıkarlarına paralel olarak, savaş propagandasında da, savaşın nedeni, Ortodoksluğu ve anavatanı koruma amacı olarak lânse edildi. O dönemde, Rus hükümetinin sansür komitesi aracılığıyla çıkan her türlü yazılı ya da görsel yayını kontrol ettiği düşünülürse, Rus hükümetinin, Ortodoksluğu hem Müslüman Türklerle hem de Ortodoks olmayan Fransız ve İngilizlerle savaşan Rusları birleştirmek ve desteklerini almak için kullandığı açıkça görülür. Her ne kadar savaş Ekim 1853 'te başlamış olsa da 1853 yılında basılmış herhangi bir lubki kitabı veya resmi yoktur. Bunun nedeni, büyük ihtimalle Nikolay’’n yayınlamış olduğu bildirilerle Osmanlı Devleti'ne karşı yeterince halk desteği sağlayabileceğini düşünmüş olmasıdır. Ancak Rusya’nın Karadeniz'deki Osmanlı donanmasını yakması ve bunun sonucunda Karadeniz’in ve Osmanlı Devleti'nin güvenliğinin tehlike altına girmesi üzerine, Fransa ve İngiltere'nin Mart 1854'te Osmanlı Devleti'nin müttefikleri olarak savaşa katılmasıyla ve özellikle Kırım Yarımadası'nda Rusya’nın askeri gücünü törpülemesiyle birlikte Rusya'da savaş propagandası niteliği taşıyan popüler edebiyat ve resim örneklerinin de basılmaya başladığı görülür. Özellikle yayınların çoğunun, Fransa ve İngiltere’nin savaşa girmesinden sonra çıtı̆̆ı düşünülürse, savaş propagandası ile tehdit algılaması arasında sıkı bir bağlantı olduğu ortaya çıkar.

Bu dönemde yazılan hikâye kitapları, resimler, makale ve her türlü basın yayın ürünü sansür komitesinin denetiminde geçmekteydi. Bu da resmî 
ideoloji, savaş propagandası ve popüler edebiyat ve resim arasında sıkı bir ilişki olduğunu gösterir. Hükümet bunu yaparken, çıkan yayınların resmî ideolojiye uygun olmasına dikkat etti. Kırım Savaşı döneminde çıkan her yayın, üyeleri çar tarafından atanan sansür komitelerinin denetiminden geçmekteydi. Aslında, Nikolay'ın basına karşı sansür uygulaması savaştan önce başlamıştır. Genel olarak otokrasiye zararlı düşünceleri engellemek ve Rus çarlığına ve Ortodoksluğa bağlllığı harekete geçirmek için, "I. Nikolay sansür komitesi, polisi ve 1832 'den sonra da basına kişisel müdahalesi ile her türlü yayını kontrol etti” (Ruud 1982: 67). Ayrıca, sansürün kalitesini arttırmak, Nisan 1848'de, (Başkanı Buturlin'in adını alan) "Buturlin Komitesini" ve "Rusya’daki Özel Yayınların Ruhu ve Eğilimini Gözleme Komitesini” kurdu. Bu komite, kurulduğu dönemde 1848 ihtilallerinin Rusyàya etki etmesini engellemek amacına hizmet etti ama bu tehlike ortadan kalkmasına rağmen, Nikolay döneminin sonuna kadar varlığını korudu. II. Aleksandr, Şubat 1855 'te Nikolay' in ölümü üzerine tahta gelince, bu komiteleri lağvetti (Ruud 1982: 86, 98).

Genel sansür politikası doğrultusunda, daha önceden hiç sansür yüzü görmeyen lubki resimleri de, 1850'den itibaren sansüre tâbi olmaya başladı. Yıllardır kendisi de bir yayıncı ve lubki satıcısı olan arkeolog-köylü I. A. Goluşev'e göre Moskova Genel Valisi Baron Zakrovskski, lubki resimlerini üreten fabrikaların sahiplerine sansür izni olmayan bütün levhaları ve resimleri yok etmelerini emretti. Bu emri yerine getiren fabrika sahipleri, bütün bakır listeleri toplayıp, onları parçalara ayırdılar (Polveka Dlya Knigi 1916: 167).

Lubkiyi sansür denetiminden geçirenlerin başında Vladimir Nikolayeviç Beketov, Nikolay Vasilyeviç Elagin (1817-1891), Nikolay Stepanoviç Ahmatov ve İvan Mihailoviç Snegirev vard.1. ${ }^{1}$ Özellikle Snegirev ve Beketov lubkiyi en çok denetleyen isimlerdi. Savaş döneminde hükümetin resmi ideolojisine uygun olarak, sansür denetiminden geçerek yaklaşık üç yüz lubki basıldı (Polveka Dlya Knigi 1916: 173). Aynı sansür, resimlerin yanı sıra her türlü basın yayın için de geçerliydi. Savaş propagandasının belirlenmesinde, yayınlara ve resimlere verdikleri onay veya ret cevapları ile, hiç kuşkusuz sansür komitesinin üyelerinin önemli bir etkisi oldu. Bunlar dışında, lubki ressamları, yazarları ve onların hedef kitlesi de, savaş propagandasının belirlenmesinde önemli roller oynadılar. 


\section{Lubki Resimlerinde Kırım Savaşı}

Kırım Savaşı döneminde, Rus ressamlar, resimlerinde genellikle 1812'de Terebenev' in işlediği temaları kullandılar. Ama 1812 resimleri ile 1853-56 resimleri arasındaki en önemli fark, Ortodoksluğun Rus ulusal kimliğinin bir öğesi olarak daha çok öne çıkarılmasıydı (Norris 139). Bunun iki nedeni vardı. Birincisi; Ortodoksluk, Rus milliyetçiliği ve otokrasiyle birlikte, Nikolay'ın resmî ideolojisinin öğelerinden birini teşkil etmekteydi (Riasanovsky 1959: 15). İkincisi, yukarıda belirtildiği üzere Rusya, Kırım Savaşı’nda, Müslüman Türkler, Katolik Fransızlar ile Protestan İngilizlerle savaşıyordu. Bu nedenle, popüler propagandada Rusları birleştirici bir unsur olarak Ortodoksluğun vurgulanması son derece mantıklıydı.

Bu ana özelliği dışında, Kırım Savaşı ile ilgili lubki resimlerinde öne çıkan diğer önemli bir husus, resimlerin Fransa ve İngiltere'den çok Osmanlı Devleti'ni konu edinmesi; Fransa ve İngiltere’nin neredeyse hiç yer almamasıyd. Resimlerde Osmanlı Devleti ya Ortodokslara baskı uygulayan zalim bir devlet ya da savaş başladıktan sonra Ruslar karşısında duramayan mağlup bir ülke olarak tasvir edilmiştir.

Savaşın başlangııından 1854 yılına dek basılan bu resimlerde öne çıkan düşman Osmanlı Devleti olduğu için, Rusyảnın savaşa giriş nedeni de doğal olarak Rusların Balkanlardaki Ortodoksları koruma amacıyla açıllanmıştır. Ama lubki resimlerinde Ortodoksları koruma politikasına yapılan referanslara rağmen en çok işlenen konu, Rus cesareti ve kahramanlığ idi. Ekim 1853 teki Başgedikler Muharebesi, Ekim 1854'teki Sinop Muharebesi ve Kasım 1854'teki Ahıska Muharebesi gibi Rusların Türklere karşı zaferler kazandığı gerçek olayları resmeden lubki, Rusları cesur ve muzaffer olarak tanımladı. Resimlere iliştirilmiş ve çoğu, Moskovskiye Vedomosti (muhafazakâr bir gazete) gibi gazetelerden alınmış haberlerden oluşan veya özellikle resimler için yazılmış yazılar da Rus cesaretini öne çıkardılar. Doğu Anadolu’da Türklere karşı kazanılmış muharebeler dışında, lubok resimleri Baltık Denizi'nde İngilizlere karşı kazanılmış deniz muharebelerini de resmettiler. Sivastopol'ü bombardımana tutan ve burada Rusya’nın yenilgisinde en önemli rolü oynayan Fransızlardan ise hiç söz etmediler. Lubok bu haliyle savaşın hizmetinde tam bir güçlü güdümleme aracıydı. 
Konu itibarıla en önemli ve Ortodoksluğun sembolik olarak kullanıldığı resimlerden biri olan "Teğmen Kudratsev'in Olağanüstü Zaferi” (Resim 1) (Norris 2006: 203) isimli resimde, Türkler tarafindan saldırıya uğrayan Ortodoksluğun ve Ortodoksların Ruslar tarafından korunması teması işlenmiştir: Arka plandaki İsa/Aziz ve Meryem heykelleri, ikonlar ve yerde yatan Ortodoks papazı, Türkler tarafından saldırıya uğramış bir kilise (Ortodoksluğun simgesi) izlenimi verir. Türklere saldıran üniformalı Ruslar ise kiliseyi koruyan gücü sembolize eder. Bu sembollerle ressam toplumsal-kolektif bilincin en zayıf en önemli duygusu olan dini duygulara hitap etmiştir.

Bu resim dışında, çoğu resmin, "cesur Ruslar ile korkak Türkler" in savaşmasını konu edindiği ve Rusların kahramanlık ve vatanseverlik duygularına hitap ettiği görülür. Rusları şevkle savaşan cesur insanlar olarak resmeden 1854 tarihli, I. M. Şamin tarafından çizilen “Subay Gonçarov’un Zaferi” (Resim 2) başlıklı lubokta, "cesur" Gonçarov silâhını büyük bir kararlılık ve cesaretle, çömelmiş bir Türk askerine doğrultmuş gözükür. Gonçarov’un ayağının altında ise ölmüş Türk askerlerinin cansız bedenleri dikkati çeker (Gosudartsvennaya Publiçnaya Biblioteka Rossii 1854: Podvig Unter Ofitsera Gonçarova). Burada, Rus cesareti ve zaferi, ölü Türk askerleri aracıllğ̆ıla verilmek istenmiştir.

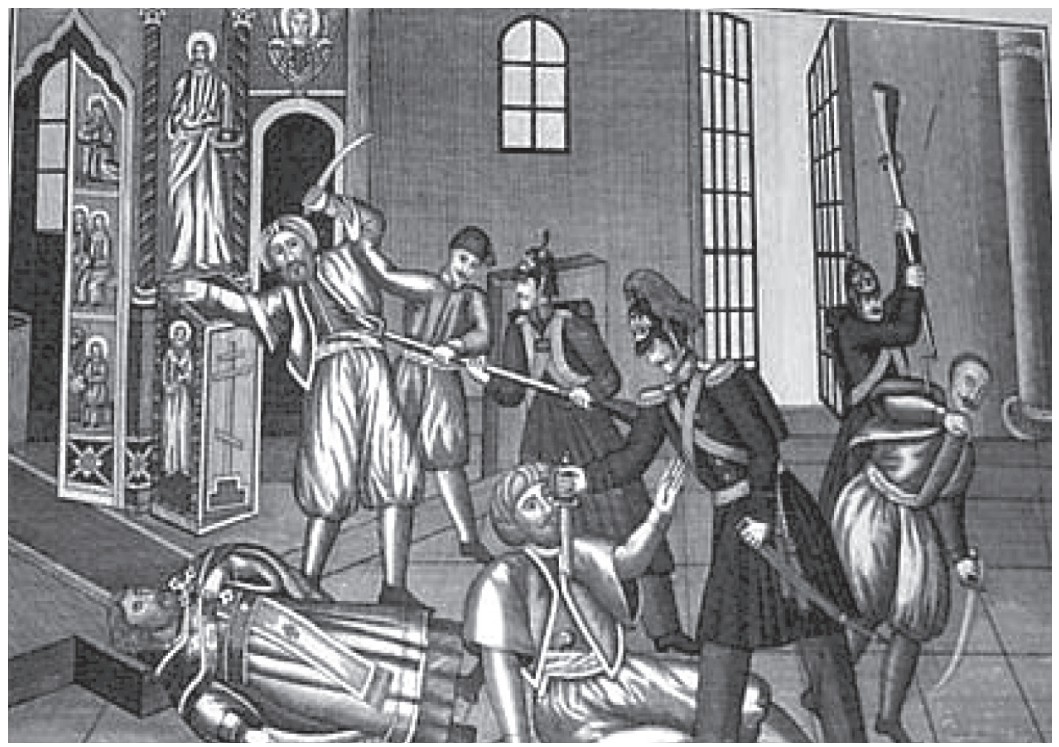

Resim 1. Teğmen Kudratsev’in Olă̆anüstü Zaferi 


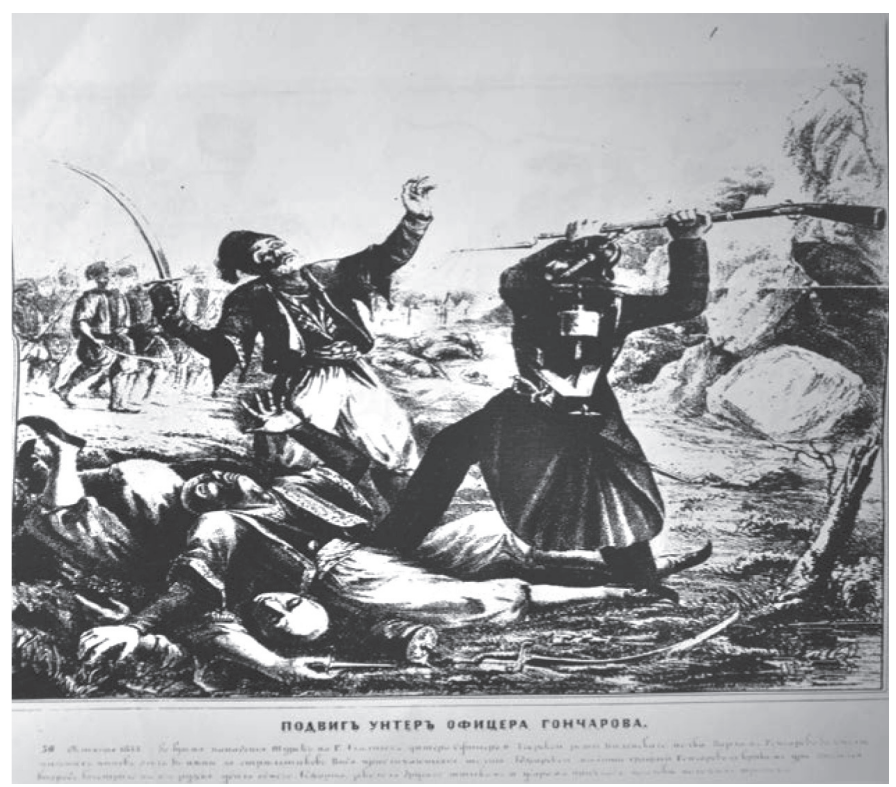

Resim 2. Subay Gonçarov'un Zaferi

Doğu Anadolu'da Türklerle Ruslar arasındaki bir muharebeyi anlatan, "Mayıs 17, 1854, Yarbay Prens Eristov'un Kumandanlığında Gurii Zaferi” (lit. L. Khitrova, A. ve V. Strel'tsova, M. 1854) başlıklı lubok da Rusların cesaretini vurgulamaya hizmet eder. Resmin altındaki metinde şunlar yazılıdır: "Yarbay Prens Eristov komutasındaki Kazaklar, Lapçakat köyünde 12.000 Türk askerine karşı bir muharebe yaptılar. Ruslar 1000 Türk askerini öldürdü, 100’den fazla insanın bulunduğu bir gönüllü birliğini esir aldı ve barut dolu iki top, 5 nişan, birçok silah ve cephane ele geçirdi" (Lebedev 1994: 6). Aslında, Lapçakat'taki Türk kaybı ile ilgili kesin bir bilgi olmamasına rağmen, metinde verilen sayılar, Rusların Türkler karşısında ne kadar güçlü olduğunu gösterme amacına yöneliktir.

“Türk Kalesi Kars’ın Zapt1, 16 Kasım 1855” (Resim 3) (Norris 2006: 201) adlı lubok da yine zafer ve cesaret temalarını işlemiştir: At üzerinde dimdik duran Rus komutan zaferi, disiplin ve cesareti, karşısındaki Osmanlı komutanı ve onun ardındaki yere diz çökmüş, başları öne eğik paşalar ise yenilgiyi temsil ederler. Ayrıca, resimde, Türk tarafındaki karmaşanın aksine, son derece muntazam ve bir çizgi kadar düzenli duran Rus birlikleri de, disiplin ve onunla gelen zafer duygusunu pekiştirmeye hizmet eder. 


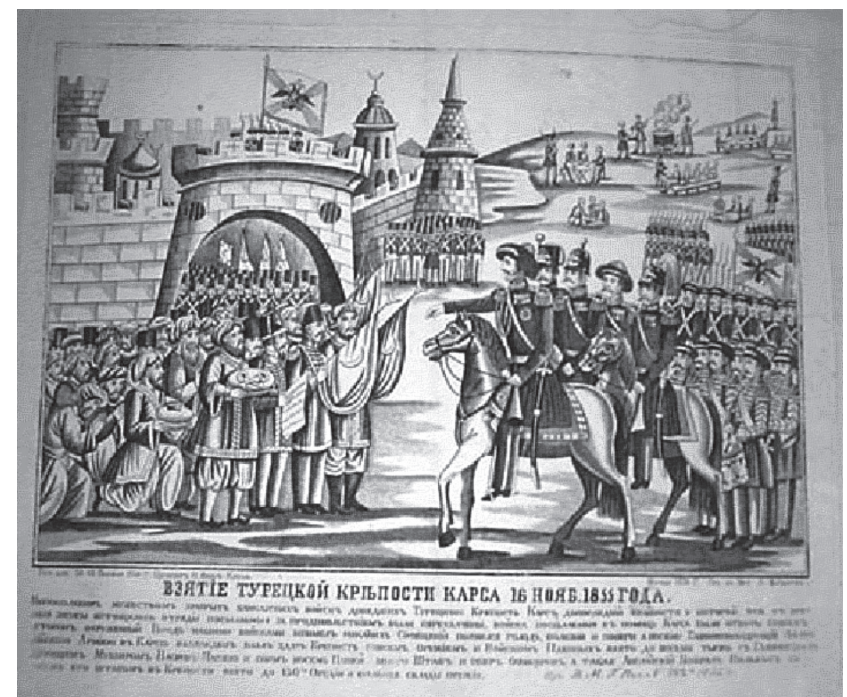

Resim 3. Türk Kalesi Karsin Zaptı, 16 Kasım 1855

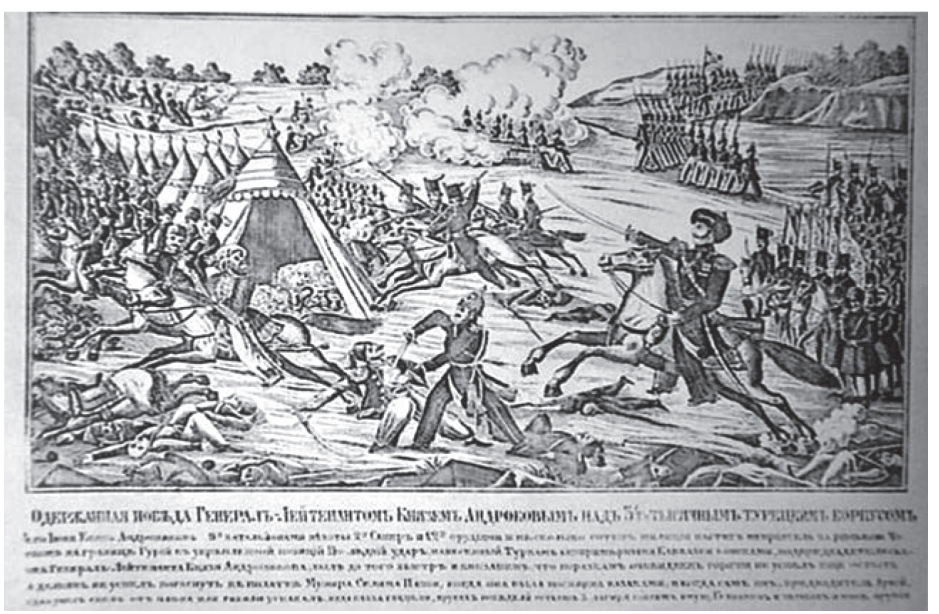

Resim 4. Korgeneral Prens Androkov'un 30.000 Türk askerine karşı Zaferi

Benzer bir şekilde, “Korgeneral Prens Androkov'un 30.000 Türk askerine karşı Zaferi” (Resim 4) başlıklı lubokta da (Norris 2006: 204) “galip Ruslar ve mağlup Türkler" imgesini vermek için düzen, intizam ve karmaşa metaforları kullanılmıştır: Saldırı halinde olmasına rağmen, hâlâ düzen ve intizamı koruyan Rus birlikleri galibiyeti, arkasına bakarak kaçan, hatta Rus askerlerinin kılıç darbeleri ile yere düşen veya çoktan hayatını kaybetmiş yerde yatan Türkler ise 
mağlubiyeti simgeler. Ayrıca, ressamın, bu düzen, disiplin ve galibiyet temasını vurgulamak için Rusları çok aralıklı ve geniş bir alana yayarken, Türkleri dar bir alana hapsedip, onları üst üste yığdığı gözlenir.

\section{Lubki Kitaplarında ve Popüler Edebiyatta Kırım Savaşı}

Kırım Savaşı döneminde propaganda amaçlı lubki resimlerinin yanı sıra, aynı ismi taşıyan, birçok küçük hikâye kitapları, şiirler ve şarkılar basılmıştır. Bu lubki kitaplarının hepsi, sansür komitesinin denetiminden geçmiş ve ne zaman, hangi sansür komitesi üyesi tarafından kontrol edildikleri iç kapaklarında belirtilmiştir. Rus toplumunun alt sınıfları başta olmak üzere bütün Ruslara yönelik olarak basılmış bu kitaplar son derece ucuz olup, fiyatları 15-25 kopek arasında değişmekteydi.

Kitapların önemli bir kısmının Ya Yonson, Karl Kraiy gibi özel şahıslar tarafından, bir kısmının ise Bilimler Akademisi ve Genel Kurmay Başkanlığı gibi kurumlar tarafından basıldığı görülür. Daha önce de bahsedildiği üzere 1853 yılında basılmış kitap neredeyse hiç yoktur. Ağırlıklı olarak 1854 ve 1855 yıllarında basılan bu kitaplar, çoğunlukla savaşın nedenleri, Rus askerlerinin kahramanlığı, çara bağlılıkları ve vatanseverlikleri gibi konuları işlemişlerdir.

Bu konuların anlatımında ise ilginçtir ki en çok şiir ve şarkı formatı kullanılmıştır. Uzun hikâyelerin ve anekdotların yer aldığı kitapların sayısı görece daha azdır. Ayrıca savaşa giden askerlerin ve kahramanlık gösteren önemli subay ve komutanların konuşturulduğu birçok piyes de bulunmaktadır. (Jertva otçizn' dramatiçeskiy epizod 1854). Nakarat ve dörtlüklerde sık sık tekrarların bulunduğu şiir ve şarkı dizeleri, savaş propagandasına yönelik sloganlar gibidirler. Bu genel özellikleri dışında lubki kitaplarının, savaşı ele alış biçimleriyle resimlerden biraz farklı olduğu görülür.

Her şeyden önce, resimlerde düşman olarak Türkler öne çıkarken, edebiyatta Fransa ve İngiltere daha çok vurgulanır. Ayrıca, savaşın nedenlerini açıklarken, düşmanları ve Rusları tasvir ederken, lubki resimlerine göre şiirlerde ve hikâyelerde görece daha sofistike bir dil ve üslup kullanılmıştır. Rusları vatansever ve kahraman; düşmanlarını ise kabaca korkak olarak tanımlayan ve savaşın nedenlerini daha çok Ortodoksları koruma amacıyla açıklayan lubki resimlerinin aksine, popüler edebiyatta ve şiirde hem savaş hem de Ruslar ve düşmanlar biraz daha ayrıntılı biçimde tasvir edilmişlerdir. Fransa, İngiltere gibi ülkelerin savaşa girme nedenleri, dine hemen hiç referansta bulunulmadan bu ülkelerin 
ekonomik politikaları veya onların emperyalist yaklaşımlarıyla açılklanmıştır. Bu özelliğiyle lubki kitapları sadece popüler halkı hedef almış gözükmezler; entelektüellerin o dönemde ele aldığı eserlerde vurguladıkları bazı nedenleri öne çıkartarak, eğitimli Ruslara da hitap etmiş gibidirler.

Rus halkının vatanseverlik duygularını ateşlemek ve teşvik etmek için popüler edebiyata hayat veren Rus şair ve yazarlar, Kırım Savaşı'nı, Fransa ve İngiltere'nin Rusyảnın gücünü yıkmak için karıştıkları emperyalist bir savaş olarak lanse ettiler. Bu doğrultuda yazılan bir hikâyede, refahı başka ülkelerin kaynaklarına dayanan İngiltere ve Fransa'nın aksine Rusyảnın ihtiyacı olan her şeye kendi topraklarında sahip olduğu belirtilir (Geroy Russkih 1856: 22).

Size, yabancılara hiç ihtiyacımız yok

Tanrı'ya şükür,

Çarımızın sağlığına

Rus romunu içebiliyoruz!

Yünlü kumaşlarınıza ve ham pamuğunuza

Ve sizin mısırınıza ihtiyacımız yok

Askerlerimiz için

Rus yapımı yünlü kumaştan üniformalarımız var

Şarabımızı kendimiz üretiyoruz

İngiliz çeliğine ihtiyacımız yok,

Kendi madenlerimiz var.

Benzer görüşler, "Hikâyeci: Osmanlılar, Fransızlar ve İngilizler Hakkında" başlıklı bir hikâyede de geçer. Bir dedenin torununa anlattığı bu hikâyede, ulusal kaynaklarıyla yetindiklerinden ve başka ülkelere ihtiyaç duymadıklarından Rusların kendileriyle gurur duyduğundan bahsedilir. Rusların kendilerine yetecek kadar ekmeği, demiri ve her şeyi olduğu vurgulanır. Topraklarının çok geniş olduğu ve denizaşırı ülkelerin insanlarının yardımı olmadan da yaşayabilecekleri belirtilir (Flemming 1854: 6). İki farklı kaynak da Rusya’nın tarım ekonomisiyle sanayisiyle öne çıkan İngiltere'den güçlü olduğunu ima eder. Rusya'nın ürettikleriyle ve sahip olduklarılla yetinen ve kendi kendine yeten bir ülke olduğuna yapılan bu vurgunun nedeni, biraz da İngiltere'nin buğday gibi tarım ürünlerini 1838 Balta Limanı Antlaşması'na kadar Rusya'dan ithal ediyor olmasıyla açıklanabilir. 
Emperyalist düşman imgesinin vurgulandığı bir diğer örnek, Sivastopol'ün 1855 'te Rusların elinden çıkmasından sonra yazılan bir şiirdir. Şiirde sadece İngiltere ve Fransa değil, artık Osmanlı da başkalarının kaynaklarına ihtiyaç duyan, hırslı ve açgözlü bir ülke olarak tanımlanmıştır (Anglo-Frantsuzkiy Desant v Krymu 1854).

Üç düşman; İngiliz, Osmanlı ve Fransızlar

Zaferlerini ve iş birliklerini kutlarken ve

Kendilerini eşit kabul ederken,

Rein, Oka, Çin'e, Tataristan’a

Cezayir'e, Arabistan'a gitmek için toplandılar!

Onlar evde oturmak nedir bilmezler

Ve her zaman başkalarına ait olanları hayal ederler.

$\mathrm{Bu}$ şiirde her ne kadar Osmanlı Devleti de başkalarının topraklarında gözü olan, yayılmacı ve sömürgeci bir ülke olarak tanımlansa da savaş dönemi popüler edebiyatta Osmanlı Devleti emperyalist bir devletten çok, Fransa ve İngiltere’nin amaçlarına ulaşmak için toprak bütünlüğünü koruduklarını ileri sürdükleri, aslında maşa olarak kullandıkları bir ülke olarak tasvir edilmiştir. Örneğin, Rusya'nın tek başına üç devletle savaşmasını konu edinen 1854 tarihli bir lubki kitabında, Türkler tam bir "ahmak" olarak; müttefikleri özellikle de İngiltere ise onun tadına varmış, onu soymaya hazır bir turna kuşu olarak tasvir edilmiştir (Odin na troikh 1854).

Amaçlarına ulaşmak için Osmanlı Devleti'ni kullanan Fransa ve İngiltere imgesine, aynı zamanda Nikolay’ın danışmanlığını da yapan Rus tarihçi Mihail Petroviç Pogodin'in (1800-1875) eserinde de rastlamak mümkündür. Hatta Pogodin, muhafazakâr Rus entelektüelleri arasında savaşı bu yönüyle ele alan tek kişidir diyebiliriz. İvan Vasilyeviç Kireyevsky (1804-1856) ve Aleksey Stepanoviç Khomyakov (1804-1860) gibi muhafazakâr Rus entelektüeller, Kırım Savaşı'nı Ortodoks Ruslarla Katolik Fransızlar ve Protestan İngilizler arasında cereyan eden kutsal bir savaş olarak tanımlarken (On Spiritual Unity 1998: 24, 65), Pogodin İngiltere ve Fransảnın Osmanlı Devleti’ni korumak bahanesiyle savaşa girme nedenlerini Rusya’nın gücünü kırmak ve onu aşağılamak olarak açıklamıştır (Pogodin 1874: 96).

Sömürgeci ülke yakıştırması en çok İngiltere'ye yapılmıştır. İngilizlerin, $k u$ laklar (Rus köylülerini sömüren zengin köylüler) gibi, ticaret ve kâr insanları 
oldukları ve amaçları için her türlü hileye ve ahlaksızlığa hazır oldukları ileri sürülmüştür. Hatta amaçları için Osmanlılarla bile ittifak yaptıkları belirtilmiştir (Razskaz Soldata Sidorova 1855: 5). 1856'da basılan ve Sivastopol savunmasında kahramanlıklar gösteren bir Rus askerinin hikâyesini anlatan bir diğer kitap da Fransa ve İngiltere'yi Osmanlı'yı mazeret olarak kullanan ama aslında emperyalist bir ajandaya sahip tehlikeli ülkeler olarak tasvir eder. "Fransızlar ve İngilizler, Sultanın onurunu ve bağımsızlığını korumak için Osmanlı Devleti ile ittifak yaptıklarını iddia ettiler ve bununla canice düşüncelerini saklamaya çalıștılar. Savaşın içine gizlice dâhil oldular ve kendilerini iyi insanlarmış gibi lanse ettiler" (Rasskaz Soldata Sidorova 1855: 5). Aynı hikâye kitabında, İngilizlerin sinsi bir millet olduğunu vurgulamak için İngilizler ve Fransızlar sürünerek Rus topraklarına giren ıstakozlar olarak resmedilmişlerdir. Ruslar ise vicdanlı ve dürüst insanlar olarak tanımlanmıştır. Bu yüzden de Rusların er ya da geç Fransız ve İngilizleri suda boğacağı belirtilmiştir (Rasskaz Soldata Sidorova 1855: 14).

Ayrıca Rus popüler edebiyatında İngilizler ve Fransızlar hem korkak hem de barbar insanlar olarak tanımlanmışlardır. Bunu vurgulamak için de birçok hikâye kitabında Odesa şehrinin Kutsal Cumartesi günü bombalanmasına ve silahsız birçok sivilin yaşamını yitirmesine işaret edilmiştir (Geroy Russkih Povedonosnıh Voysk 1856: 22):

Odesa’nın hain bir biçimde bombalanması İngiliz ve Fransızların barbarlığına ve insanlıklarının olmayışına işaret eder. Korkak insanlar gibi müstahkem şehirlerden uzak dururken, herkese açı bir ticaret şehrini bombalayarak oradaki sivilleri öldürmeleri dünyayı da şaşkına çevirmiştir. Böyle davranarak uzun zamandan beri tasarladıkları amaçlarına ulaştılar mı? Kesinlikle hayır. Şan şöhret istemişlerdi ama lanetle ve şerefsizlikleriyle öne çıktılar.

Hikâye kitaplarında Türklerden çok İngilizler ve Fransızlar üzerinde durulması, bu iki ülkenin Osmanlı Devleti'nden çok daha büyük bir tehdit olarak algılanmasından kaynaklanmaktadır. Özellikle Sivastopol kuşatmasına ve bombalanmasına vurgu yapılması da bundandır. Çünkü Fransızlar burada Ruslara büyük bir üstünlük sağlamışlar ve Sivastopol'ün düşmesinden sonra Kırım Rusya’nın elinden çıkmışır. 
Fransa ve İngiltere emperyalist devletler olarak tanımlanırken; Rusya, lubki resimlerinde olduğu gibi, Balkanlardaki Ortodoksları Türklerden korumak için savaşa giren insancıl ve Ortodoks bir ülke olarak tanımlanmıştır. Ancak bu vurgu, 1877-78 Savaşı'nda olacağı gibi çok güçlü değildi. Çünkü lubki kitapları, savaş başladıktan sonra, özellikle 1854-1855 yıllarında basıldıklarından, Rusya’nın savaşa girme nedenlerinden çok, onun düşmanlarıyla özellikle Fransa ve İngiltere'yle nasıl baş ettiğiyle veya edebileceğiyle daha ilgiliydiler.

Bu bağlamda lubki kitaplarında Rusların askeri gücüne bazı referanslarda bulunulsa da düşmana karşı başarıyı ve direnci mümkün kılan ana faktör olarak Rus askerlerinin ve komutanlarının kahramanlıkları ve onların dinlerine, çarlarına ve vatanlarına bağlılıkları öne çıkarılmıştır. Örneğin bir şarkıda Rus askerler, baba çar ve anavatanın çocukları olarak mutlu bir şekilde düşmanı bulmaya ve onu öldürmeye giderler (Russkiy Patriot ili Voyna s Turkami 1854):

Türk'ü öldürme zamanı

Mutlu bir şekilde gidiyoruz

Ve düşmanı bulacağız.

Biz [askerler] hepimiz kardeşiz

Çar babamız, vatan anamız!

Yüzyılların şanıyla

Tekrar geliyoruz

Her birimiz cesur-genç bir savaşçı,

Sevgili babamızı-çarımızı-mutlu edelim.

Benzer şekilde, 1854 yılına ait bir şiirde, Ruslar Fransız, İngiliz ve Türklerin üçüne birden karşı çara ve vatanlarına sevgi ve bağlılıklarıyla karşı durabilen bir Rusya resmi çizilmiştir (Semerihin 1854):

İşte Fransızlar, İngilizler ve Türkler

Düşmana yiğitlik neymiş, Rus askeri nasılmış göstermenin zamanı geldi.

O-Rus askeri - inançlarının arkasında sağlam bir şekilde duruyor

Savaş meydanında uralar patlıyor

Üzerimize gelen düşmana karşı

Ölümcül bir anda

Kalabalıklar ateşli bir biçimde kutsal Rus için ve baba-çar için

Canını vermek için savaşıyor. 
"Kılıç ve Takım Yıldızı" isimli bir başka şiirde de Rusya’nın çok zengin ve güçlü bir ülke olduğu belirtilmiş ve kendisinin hiçbir hükümetle karşılaştırılamayacağı vurgulanmıştır. Bu gücün nereden geldiği açıklanmamışsa da en son dizelerde yer alan "Kutsal Rus ve çar için ölmeye hazırrz" cümlesinde bunun yine çar ve vatan sevgisinden kaynaklandığı ima edilmiştir (Meç' i Lira 1855: 4). Bütün bu şiirlerde, Rusya büyük bir aile gibi anlatılmıs, anavatan, baba çar ve onların çocukları olan askerler de bu ailenin bireyleri gibi tasvir edilmiştir. Baba-çar imgesiyle, Çar Nikolay'ın, "Ortodoksluk, Rusluk ve otokrasi” olarak özetlenebilecek resmî ideolojisine uygun biçimde otokrasiye de referansta bulunulmuş ve otokrasiye olan bağll lıkları ve sevgileri Ruslara savaşma gücü veren bir etken olarak öne çıkarılmıştır.

Kırım Savaşı sırasında Rus popüler kültüründe en çok bahsi geçen olay, daha önce bahsedildiği üzere, Sivastopol'ün Fransızlar tarafindan kuşatılması ve bombardımana tutulmasıdır. Bu olayda Rusya kaybettiği halde, şiirlerde kazanan taraf odur. Ruslar düşmanlarını öldürmüşlerdir; "Bütün şehir onların cesetleriyle doludur; 1,060'ını esir almışlardır. Ölülerini ise saymak mümkün bile değildir. Çar, Sivastopol'ü savundukları için askerlerin hepsine altın para dağıtmış ve onlar için sarayda yemek vermiştir (A-i-da Abdul'! Vseh v Parije 1855).

Yine Rusları savaşmaya teşvik etmek için her ne kadar olay 1854 'te cereyan ettiyse de $1855^{\prime}$ te, Sivastopol Muharebelerinin yapıldığı ve savaşın kaderinin belirlendiği yılda, 1854'te Rusların Osmanlı Devleti'nin Karadeniz donanmasını yakmasını anlatan ve bunu bir başarı olarak tasvir eden hikâye kitapları basılmıştır. Bunlardan birinde, "cesur denizci” Menşikov ve Rusya'nın düşmanlarını korkutan kahraman Prens Gorçakov’un denizi ve dağları dize getirdiğinden, harikulade Kornilov ve Nahimov'un, Sinop Muharebesinde gemileri yaktığından ve "bütün Avrupa’yı şaşırtarak Osmanlının şanlı donanmasına 500 bomba attıklarından" bahsedilir. Bombaların etkisiyle "yer sarsılmış, Karadeniz çalkalanmış, dağlar titremiş ve Müslümanların filosu yanmıştır (Podvigi Russkih Geroyev 1855).

Savaşın sonuna doğru, 1856 'da basılmış bir hikâye kitabında vatanseverlik, yine Rus askerlere savaşma gücü veren bir etken olarak vurgulanmıştır. Kitapta, askerler bayrağı yere düşmeden kanlarının son damlasına kadar taşıllar çünkü bayrak ülkelerini ve Rus onurunu simgeler (Geroy Russkih Pobedonosnuh Voysk 1856: 19): 
Bayrağı taşıyan asker ölümcül bir biçimde yaralanmıştı. Yere düştü ama bayrağın yere düşmesine izin vermedi. Son nefesini, bayrağı dizlerinin üstünde tutup, göğsüne koymak için kullandı. Onun nefesinin kesildiğini fark eden diğer dört asker bayrağı ölen askerden aldılar. O dört asker de bayrağı yere düşürmemek için canlarını feda ettiler. Ölürken bile bayrağı yere düşürmemek için uğraşıyorlardı. Bunu gören düşman bize karşı koyamayacağını anladı ve kaçtı.

Bu hikâyenin, savaşın sonunda bile Ruslara pes etmemeleri gerektiği duygusunu aşılama ve söz konusu meselenin Rus onuru ve vatanı olduğunu hatırlatarak onları savaşmaya devam etmeleri için teşvik etme amacı taşıdığı açıktır.

Kırım Savaşı döneminde, lubok resimlerinin ve kitaplarının halka ne kadar ulaştığı ve halkın da bunlara nasıl tepkiler verdiği konusunda net bir bilgi yoktur. Bununla birlikte, halkın savaşa desteği konusunda bazı çalışmalar mevcuttur. Wirtschater'ın Serften Rus Askerine ve David Moon'un Rus Köylüleri ve Reform Arifesinde Çarlık Yasaları Çalışmaları Rus halkının savaşı desteklemek konusunda çok da heyecanlı olmadığını; hatta bazılarının savaşa gitmemek için elinden gelen her türlü yola başvurduğunu gösterir. En çok başvurulan yöntem, fiziksel olarak bedene zarar vermekti. Parası olan bazı varlıklı köylüler için en yaygın yöntem ise para ile kendilerinin veya oğullarının yerine askere gidebilecek kişiler bulmaktı (Keep 1985). Bu realitede, köylülerin ekonomik endişeleri önemli bir rol oynamıştır: "Bir aile için, aile bireylerinden birisinin askere alınması ekonomik yıkım anlamına geliyordu. Bir ailenin son ekmek kazanan bireyi de orduya alınınca, geride kalanların hayatını idame ettirmesi için köy halkının sağlayacağı destek yetersiz kalabilirdi” (Wirtschafter 1997: 22).

David Moon ise orduya gönüllü yazılanların bile, dini ve milli duygulardan çok, ekonomik gerekçelerle hareket ettiklerini belirtir ve birçok köylünün orduya hükümetin gönüllü olarak orduya yazılanları serflikten azat edeceğini duydukları için yazıldığını ileri sürer (Moon 1992: 118). Moon’a göre köylülerin gönüllü olarak orduya katılmasının bir diğer ekonomik sebebi de orduda evdekinden çok daha iyi durumda olacaklarına inanmalarıydı (Moon 1992: 125).

Netice itibariyle Rusların özellikle köylülerin savaşa daha çok ekonomik sebeplerle katıldıkları ve 1850'lerde Balkanlardaki siyasi durumun hem resmi manifestolarda hem de lubkideki propagandada iddia edildiği gibi çok da kaotik olmadığı düşünülürse, "Ortodoksları ve Slavları Türklerin katliamından korumak" bahanesinin halk nazarında biraz havada kaldığı söylenebilir. 
Bununla birlikte halkın savaşa desteği anlamında etkisi ne olursa olsun, Kırım Savaşı dönemindeki lubok resimlerinin ve kitaplarının, halkın zihninde belli bir iz bıraktıkları görülür. Özellikle işledikleri konu, kullandıkları semboller ve üslûp açısından daha sonraki savaşlarda, özellikle, lubkinin yoğun bir biçimde manipülâsyon aracı olarak öne çıktığı 1877-78 Osmanlı-Rus Savaşı döneminde, başvurulan propagandaya kaynaklık ettikleri ve bu yönüyle Türk imgesinin kuşaktan kuşağa geçmesine yardımcı oldukları söylenebilir.

\section{Notlar}

1 Bu sansürlerden en önemlileri, 1809 doğumlu, 1830'dan 1860'a kadar St. Petersburg Sansür Komitesi’nde çalışan Vladimir Nikolayeviç Beketov idi. Sansür komitesinin diğer bazı önemli üyeleri ise şunlardı: Nikolay Vasil’yeviç Elagin (1817-1891): 18481857 tarihleri arasında değişik dönemlerde St. Petersburg Komitesinde görev aldı. Nikolay Stepanoviç Akhmatov, St. Petersburg Sansür Komitesi'nin 1850'lerdeki diğer bir üyesi ve İvan Mikhailoviç Snegirev (1810'dan 1820 ve daha sonra 1828'den 1855'e kadar Moskova Sansür Komitesi'nde görev yaptı. (Mez’er 2000: 22-103).

\section{Kaynaklar}

A-i-da Abdul'! Vseh v parije obmanul ili donesenie Tatarina lyudoviku napoleonu o vzyatii sevastopolya (1855). Sankpeterburg: Tip. L. Dmitriyeva.

Andıç, Fuat ve Süphan Andıç (2002). Kırım Savaşı Ali Paşa ve Paris Antlaşması. İstanbul: Eren Yay.

Anglo-Frantsuzkiy Desant v Krymu. Sevastopol vzyat? (1854).

Aysal, Necdet (2013). "Kırım Savaşı'ndan Lozan Barış Antlaşması'na Osmanlı Dış Borçlarının Tarihsel Gelişim Süreci (1854-1923)”. Ankara Üniversitesi Türk Inkılap Tarihi Enstitüsü Atatürk Yolu Dergisi 13/53: 1-28.

Badem, Candan (2010). The Ottoman Crimean War: (1853- 1856). London: Brill.

Badem, Candan (2006). "Rus ve Sovyet Tarih Yazımında Kırım Savaşı". Toplumsal Tarih 155: 16-23.

Başbakanlık Devlet Arşivleri Genel Müdürlüğü (2006). Osmanlı belgelerinde Kırım Savaşı (1853-1856). Ankara: Osmanlı Arşivi Daire Başkanlığı Yayın Nu: 84.

Başer, Alper (2010). "Kırım'da Rus Kolonizasyonu (1783-1850)". Karadeniz Araştırmalart Dergisi 24: 29-42.

Bayraktar, Hilmi (2008). “Kırım Savaşı Sonrası Adana Eyaleti’ne Yapılan Nogay Göç ve İskânları (1859--1861)”. Bilig-Türk Dünyası Sosyal Bilimler Dergisi 45: 45-72.

Bayraktar, Hilmi (2007). "Kırım ve Kafkasya’dan Adana Vilayeti’ne Yapılan Göç ve İskânlar (1869-1907)”. Selçuk Üniversitesi Türkiyat Araştırmaları Dergisi 22: 405-434.

Besbelli, Saim (1977). 1853-1856 Osmanlı-Rus ve Kırım Savaşı Deniz Harekâtı. Ankara: Genkur Basımevi.

Bogdanoviç, M. Ivanoviç (1876). Vostoçnaya Voyna, 1853-56 godov. St. Peterburg. 
B. N. (1855). Rasskaz Soldata Sidorova o voennyh sobytyah proyshodivşih pri bombardirovaniy Sevastopolya Anglo-Frantsuzami. Moskva.

Budak, Mustafa (1993). 1853-1856 Kırım Savaşı'nda Kafkas Cephesi. Doktora Tezi. İstanbul.

Çakır, Ömer (2009). “Tanzimat Sonrası Türk Edebiyatının Kaynaklarından Biri Olarak Harpler I: Kırım Harbi (1853-1856)”. Turkish Studies V4/1-II: 1823-1874.

Dağlar, Oya (2004). "Kırım Savaşı'nda Orduların Sağlık Durumu ve Bir Belge”. T⿰рp Tarihi Arasttrmaları 12: 41-57.

Demirel, Muammer (2005). "Kırım Savaşı'ndan Sonra Eskişehir'e Yerleştirilen Göçmenler”. Atatürk Üniversitesi Türkiyat Araştırmaları Enstitüsü Dergisi 12/28: 311-329.

Demirtaş, Mehmet (2011). "Osmanlıya Gelen Kırım ve Kafkasya Göçmenlerinin Sorunları”. Bilig-Türk Dünyası Sosyal Bilimler Dergisi 57: 17-44.

Demirtaş, Mehmet (2009). "Kırım Savaşı ve 93 Harbi Sürecinde Osmanlı Memleketine Gelen Göçmenlerin Sevk ve İskânları”. Atatürk Üniversitesi Türkiyat Araştırma Enstitüsü Dergisi 41: 215-238.

Eldem, Ethem (2006). "War and Symbolism: Ottoman Medals and Decorations During the Crimean War". Kırım Savașinin 150nci Yilı. 150th Anniversary of the Crimean War. Istanbul 30-37.

Flemming, Karl Magnusoviç (1854). Rasskazçik: o Ottomanah, angliçanah i Frantsuzah. St. Peterbug: Ekpersta.

Geroy Russkih Povedonosnıh Voysk, zaşçitniki very, tsarya i oteçestva protiv anglo-Ottomano-Frantsuzov ili voennyya sobytiya nastoyaş̧̧avo vremeni (1856). Moskva.

Gürel, A. Tevfik (1935). “1853-55 Türk-Rus ve Müttefiklerin Kırım Savaşı”. Askeri Mecmua 97.

Jelavich, Barbara (1974). St. Petersburg and Moscow: Tsarist and Soviet Foreign Policy, 1814-1974. Bloomington: Indiana University Press.

Karasu, Cezmi (1998). Kırım Savaşı Sırasında Osmanlı Diplomasisi (1853-1856). Doktora Tezi. Ankara: Ankara Üniversitesi.

Kazas, Elvira (1994). 1853-1863 Yıllarında Kırım'dan Osmanlı Topraklarna Yapılan Göçler. Yüksek Lisans Tezi. İstanbul: Marmara Üniversitesi.

Keep, John L. H. (1985). Soldiers of the Tsar. Army and Society in Russia, 1462-1874. Oxford: Clarendon Press.

Keleş, Erdoğan (2010). “Kırım Savaşı’nın (1853-1856) Finansmanı ve Buna Dair Bir Defterin Değerlendirmesi”. OTAM 27: 107-141.

Keleş, Erdoğan (2008). "Kırım Savaşın'nda (1853-1856) Karadeniz ve Boğazlar Meselesi”. Ankara Üniversitesi Osmanlı Tarihi Araștırma ve Uygulama Merkezi Dergisi 23: 149-194.

Lebedev, I. V. (1994). Russki Voennyi Lubok: iz kollektsiy otdela redkih knih. Moskva. Meç' i Lira. Sovremennyya stihotvoreniya soçinenie V. D. (1855). S. Peterburg.

Mez'er, Avgusta Vladimirovna (2000). Slovar' Russkih Senzorov. Moskva: Gosudarstvennaya Publiçnaya İstoriçeskaya Biblioteka Rossi.

Moon, David (1992). Russian Peasants and Tsarist Legislation on the Eve of the Reform: Interaction between Peasants and Officialdom, 1825-1855. The Macmillian Press Ltd. 
Norris, Stephen (2006). A War of Images: Russian Popular Prints, Wartime Culture and National Identity, 1812-1945. Northern Illinois University Press.

Odin na troih ili john-bul, rober-maker i abdul-aga protiv sily bogatyreva (1854). St. Peterburg: tip. Ştaba otdel. Korp. Vnutr. Straji.

On Spiritual Unity, A Slavophile Reader, Aleksei Khomiakov, Ivan Kireevsky with Essays by Yuri Samarin, Nikolai Berdiaev and Pavel Florensky (1998). Translated and edited by Boris Jakim and Robert Bird. Lindisfarne Books.

Özcan, Besim (1998). "Kırım Harbi Sırasında Bazı Avrupalı Devlet Adamlarının Osmanlı Ülkesine Ziyaretleri (1854-1855)”. OTAM 9: 287-321.

Pançevskii ve Vladimirov (1854). Jertva otçizn’ dramatiçeskii epizod iz sovremennoy narodnoy jizni $v$ odnom deystvii, $v$ stikah $i$ proz. Sanktpeterburg v tip. İmp. Akademi nauk.

"Paskevich's Letters to Mikhail Dimitrievich Gorchakov (1876). Russkaya Starina 15: 1.

Pinson, Marc (1993). Kırım Savaşı'ndan Sonra Osmanlılar Tarafindan Çerkeslerin Rumeli’ne İskânı. Çev. Erol Taymaz. Ankara: Kafdağı Yay.

Pinson, Marc (1973). "Ottoman Colonization of the Crimean Tatars in Bulgaria 1854-1862”. VII. Türk Tarih Kongresi Bildirileri. C. II. Ankara: TTK Yay.

Pinson, Marc (1972). "Russian Policy and the Emigration of Crimean Tatars to the Ottoman Empire 1854-1862”. Güney Doğu Avrupa Araştırmaları Dergisi 1:37-55.

Pogodin, Mikhail Petroviç (1874). Istoriko-Politiçeskiya pisma I zapiski v prodoljenii Krymskoy voiny, 1853-1856. Moskva.

Polveka Dlya Knigi: Literaturno-Hudojestvennyi Sbornik, posvyaş̧̧ennyi pyatidesyatiletiyu izdatel'skoy deyatel'nosti I. D. Sytina, 1866-1916 (1916). Moskva: I. D. Sytin.

Puryear, Vernon John Puryear (1965). England, Russia, and the Straits Question, 18441856. Hamden, Connecticut: Archon Books.

Reskripty I Pisma Imperatora Nikolaya I k' Knyazyu Menşikovu za vremya Sevastopol'skoy Oborony (1908). S. Peterburg: izdal' A. I. Anisimov.

Riasanovsky (1959). Nicholas I and Official Nationality in Russia, 1825-1855. Berkeley and California Press: University of California Press.

Russia and the English Church during the Last Fifty Years (1895). vol. 1. Containing a correspondence between Mr. William Palmer Fellow of Magdalen College, Oxford and Khomiakov, in the years 1844-1854. Ed. By W. J. Birkbeck. London: Rivington.

Ruud, Charles A. (1982). Fighting Words: Imperial Censorship and the Russian Press, 1804-1906. Buffalo, London, Toronto: University of Toronto Press.

Sarınay, Yusuf (2006). Osmanlı Belgelerinde Kırım Savaşı (1853-1856). Ankara: Başbakanlık Devlet Arşivleri Genel Müdürlügü Yay.

Savaștan Barışa. 150. Yıldönümünde Kırım Savaşı ve Paris Barı̧̧ Antlaşması (18531856), Bildiriler Kitabı (2006). İstanbul: İstanbul Üniversitesi Tarih Araştırma Merkezi Yay.

Semerikhin, Ivan (1854). Soyuzniki u sevastopolya. Pismo Frantsuza k priyatelyu na rodinu. S. Peterburg, v tip Karla Krayya.

Serbestoğlu, İbrahim (2006). "Kırım Savaşı Sonrasında Samsun'da Göç ve Göçmen Sorunu”. Geçmişten Geleceğe Samsun. Ed. Cevdet Yılmaz. Samsun: Samsun Büyükşehir Belediyesi Kültür ve Eğitim Hizmetleri Daire Başkanlığı Yay. 
Sertoğlu, Midhat (2011). Mufassal Osmanl Tarihi. Resimli-Haritalı. Ankara: TTK Yay.

Sirer, Münir (1 Şubat 1965). "Kırım Savaşı ve Sivastopol Zaferleri”. Hayat Tarih Mecmuast 1/1: 31-40.

Süer, Hikmet (1976). “Kırım Harbi Kafkas Cephesi Özeti (1853-1856)”. Askeri Tarih Bülteni 3/6: 33-49.

Şahin, Hasan (1998). “Kırım Harbi (1853-1856) Öncesinde Erzurum Eyaletinde Doğu Anadolu Kafkas Sınırında Meydana Gelen Karışıklıklar”. Atatürk Üniversitesi Türkiyat Araştırmaları Enstitüsü Dergisi 9: 159-164.

Şahin, Hasan (1999). "Kırım Savaşı (1853-1856) Sırasında Rusların Doğu Anadolu’daki Aşiretleri Elde Etme Gayretleri”. Atatürk Üniversitesi Türkiyat Araştırmaları Enstitüsü Dergisi 11: 217-224.

Şimşek, Eyyub (2013). “Kırım Savaşı'nın Trabzon Eyaleti'ne Toplumsal Etkileri”. History Studies: 273-291.

Şimşir Bilâl N. (1985)."Kırım Savaşı Arifesinde Mustafa Reşit Paşa’nın Yazışmaları (91 belgeyle birlikte)”. Mustafa Reşit Paşa ve Dönemi Semineri Bildiriler. Ankara: TTK Yay.

Taşkın, Figen (2007). Kırım Savaşı’nın Osmanlı Imparatorluğu’na Ekonomik Etkileri ve İaşe Sorunu. Doktora Tezi. İstanbul: İstanbul Üniversitesi.

Tatarinov, P. (1854). Russkii Patriot ili Voyna s Turkami i Anglo-Frantsuzami. Sankt-Peterburg.

Terzioğlu, Arslan (1991). "Kırım Harbi Esnasında Osmanlı Hastaneleri ve Dünya Hastaneciliğine Etkileri”. Tarih ve Toplum 15/85: 39-46.

Türk Tarih Kurumu (2008). Muâhedât Mecmûası. IV. Cilt.

Ünalp, F. Rezzan (2013). “İlklerin Savaşı: Kırım Savaşı 1853-1856”. Askeri Tarih Araştırmalar Dergisi 22: 1-17.

Slade, Adolphus (2012). Müşavir Paşánın Kırım Harbi Anıları. Çev. Candan Badem. İstanbul: Türkiye İş Bankası Yay.

Wirtschafter, Elise Kimerling (1997). Social Identity in Imperial Russia. DeKalb: Northern Illinois University Press.

Yıldız, Netice (1984). "İngiliz Basını ve Arşiv Belgeleri Işı̆̆ında Kırım Savaşı İle İlgili Bazı Sosyal Etkinlikler”. Tarih ve Toplum 18/103: 24-29.

Yüksel, Ahmet ve Zafer Karademir (2012). "Ulema, Göç ve Devlet: Kırım Harbi’nden Sonra Osmanlı Ülkesine Göç Eden Ulemanın İskânına Dair Bazı Bilgiler”. Ankara Üniversitesi Dil ve Tarih-Coğrafya Fakültesi Tarih Bölümü Tarih Araştırmaları Dergisi 31/51: 253-276. 


\title{
Propaganda during the Crimean War (1853-1856): Images of the War and the Enemies in Russian Popular Culture*
}

\section{Kezban Acar ${ }^{* *}$}

\begin{abstract}
Fought among Russia and the Ottoman Empire, France and England, the Crimean War of 1853-56 resulted in the defeat of Russia. Even though Russia had some successes against the Ottoman Empire in the Eastern front, it couldn't hold it against France in the Crimea and was defeated by English naval power. Despite this fact, lubki books and pictures published during the war depicted Russia as victorious. Examining some examples of lubki pictures and books, this article aims to analyze Russian war propaganda during the Crimean War.
\end{abstract}

\section{Key Words}

Crimean War, lubki, Russia, Ottoman Empire, England, France.

\footnotetext{
Date of Arrival: 10 November 2016 - Date of Acceptance: 03 January 2017 You can refer to this article as follows:

Acar, Kezban (2019). "Kırım Savaşı (1853-56) Döneminde Propoganda: Rus Popüler Kültüründe Savaş ve Düşman İmgesi”. bilig - Türk Dünyası Sosyal Bilimler Dergisi 88: 113-136.

** Prof. Dr., Celal Bayar University, Faculty of Science and Letters, Department of History - Manisa/ Turkey ORCID ID: https://orcid.org/0000-0003-4702-9778 kacar45@yahoo.com
} 


\title{
Пропаганда во времена Крымской войны (1853-1856): образы войны и врагов в российской популярной культуре
}

\section{Кезбан Аджар}

\begin{abstract}
Аннотация
Восточная (Крымская) война между Россией и Османской империей, Францией и Англией закончилась поражением России. Даже при том, что она имела некоторые успехи против Османской империи на Восточном фронте, Россия не была столь успешна в противостоянии с Францией в Крыму, а также уступала морским силам Англии. Несмотря на этот факт, издаваемые в России с целью агитации простого населения во время войны лубочные картинки, книги и стихи представляли Россию победительницей. В данной статье на примере лубочных картинок анализируется российская военная пропаганда в течение Крымской войны.
\end{abstract}

\section{Ключевые слова}

Крымская война, лубо́к/лубки, Россия, Османская империя, Англия, Франция

\footnotetext{
Поступило в редакцию: 10 ноября 2016 г. - Принято в номер: 3 января 2017 г. Ссылка на статью:

Acar, Kezban (2019). "Kırım Savaşı (1853-56) Döneminde Propaganda: Rus Popüler Kültüründe Savaş ve Düşman İmgesi”. bilig - Türk Dünyast Sosyal Bilimler Dergisi 88: 113-136.

*** Проф., д-р, Университет Джелал Баяр, факультет естественных наук и литературы, кафедра истории - Маниса / Турция ORCID ID: https://orcid.org/0000-0003-4702-9778 kacar45@yahoo.com
} 